$\frac{\text { Jpn. J. Pharm. Health Care Sci. }}{\text { ノ - }}$

\title{
当院消化器外科における入院患者の腎機能と 腎排泄型薬剤の使用動向との関係
}

\author{
新岡丈典 $*^{*} \dagger^{1}$ ，竹内博行 $\dagger^{1}$ ，鳴海俊治 $\dagger^{2}$ ，川崎仁司 $\dagger^{2}$ ，袴田健一 $\dagger^{2}$ ，小田桐弘毅 $\dagger^{2}$ ， \\ 森田隆幸 $\dagger^{2}$ ，佐々木睦男 $\dagger^{2}$ ，佐藤淳也 $\dagger^{1}$ ，菅原和信 $\dagger^{1}$ \\ 弘前大学医学部附属病院薬剂部 ${ }^{1}$ \\ 弘前大学医学部第 2 外科 ${ }^{2}$
}

\section{Relation between Kidney Function and Use Trend of Renal Excreted Agents on Inpatients of Digestive Organ Surgery in Hirosaki University Hospital}

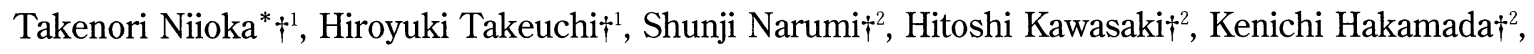

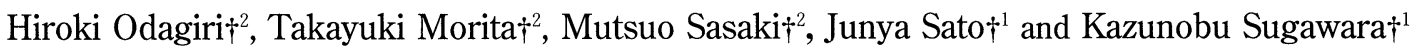 \\ Department of Pharmacy, Hirosaki University Hospital $\dagger^{1}$ \\ Second Department of Surgery, Hirosaki University School of Medicine $\dagger^{2}$
}

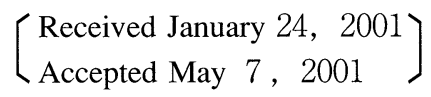

When renal excreted agents are administered to patients, it is important to understand the kidney functions of patients. We therefore investigated the use trend of renal excreted agents and the kidney function on inpatients after undergoing digestive organ surgery in order to select the most suitable agents in nephropathy. Antibiotics were most frequently used in digestive organ surgery are mostly renal excreted agents. These agents were often administered to patients whose creatinine clearance levels were less than $60 \mathrm{~mL} / \mathrm{min}$. These patients require an optimal dosage of antibiotics because most antibiotics correlate with the creatinine clearance level. The predicted creatinine clearance, as calculated by the Cockcroft-Gault formula, is often used in clinical practice to evaluate the kidney function. In this case, we must consider the difference between the observed and the predicted creatinine clearance level. If we determine the optimal dosage by the predicted creatinine clearance, the dose of flomoxef or levofloxacin were underestimated in approximately $30 \%$ of patients treated with these agents. Therefore, the creatinine clearance of patients must be assessed by evaluating such vital signs as the urine volume in addition to the serum creatinine level. In addition, pharmacists must pay careful attention to the clinical characteristics in addition to the kidney function of patients when determining the optimal dosage of renal excreted agents.

Keywords — renal excreted agents, creatinine clearance, antibiotics, Cockcroft and Gault equation

\begin{tabular}{|c|c|}
\hline 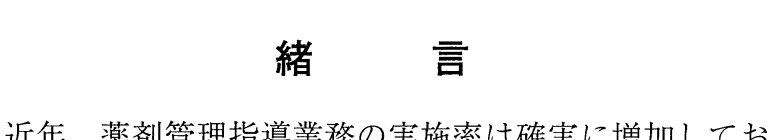 & $\begin{array}{l}\text { り, 次に問われるのはその内容, 質的側面である. その } \\
\text { ためにもわれわれ薬剤師は, ファーマンューティカル }\end{array}$ \\
\hline 近年, 薬剤管理指導業務の実施率は確実に増加してお & ケアを通じて医薬品の副作用や相互作用を回避する, あ \\
\hline
\end{tabular}


るいは早期に発見, 対処するなどといったプレアボイド を意識した業務の取り組みが重要となる ${ }^{11}$ 。また薬剤管 理指導を行うにあたり, 診療科における患者の病態や使 用される薬剤の特徵を把握することも重要である.

現在, われわれは弘前大学医学部附属病院消化器外科 において薬剤管理指導業務を展開しているが，患者に使 用される薬剤の排泄経路を調査したところ, 抗菌薬や $\mathrm{H}_{2}$ 遮断薬, NSAIDs などの腎排泄型薬剤が非常に多く用 いられていることが判明した。これら薬剤において最も 使用頻度が高かった抗菌薬の多くは，一般的に未変化体 のまま腎から排泄されることが知られており ${ }^{2)}$, 不十分 な腎機能評価による患者への過㮃投与が血中濃度上昇に 伴う副作用症状を誘発したり，また投与量が少なすぎる ため有効血中濃度が得られず感染症を悪化したりするな どの, 時として致命的な状態を招く可能性も考えられ る. 特に当科における入院患者は高齢者が多く, 体重に 占める筋肉の割合が減少しているため, 血清クレアチニ ン值(S-CRE) が正常であっても腎機能が低下している 可能性があり ${ }^{3,4)}$, 薬剤の腎クリアランスを過剰に評価 する危険性があるため注意が必要である。したがって, 患者の腎機能を正しく評価し, 投与する薬剤の体内動態 を十分把握したうえで適切な投与設計を行うことは副作 用を未然に防ぐためにも，また医療における経済効率を 高めるためにも非常に重要である.

そこで今回われわれは，当科において使用頻度が高い 腎排泄型薬剤の使用動向および体内動態に関する情報を 収集，整理し，これらの情報を医師および患者にフィー ドバックするという形で今後の薬剤管理指導業務に反映 させることを目的に，それら薬剤の使用頻度と実際投与 された患者のクレアチニンクリアランス值 $(\mathrm{CCr})$ との 関係を調査した。

\section{調查方法}

調査の開始にあたり，消化器外科における薬剤の使用 動向を把握するため，2000年 6 月の 1 カ月間における注 射薬, 内服薬の薬効分類別延べ処方日数を集計した。集 計結果において使用頻度が高く，腎排泄型薬剤が最も多 い薬効分類に属する薬剤を調査対象薬剤とした.

調査期間は1999年 8 月 1 日〜2000年 7 月31日までの 1 年間とし，期間内に薬剤が処方されたすべての患者を調 査対象患者とし，これらの患者群において処方された各 調査対象薬剂の使用人数を集計した. 各薬剤の腎排泄率 はインタビューフォームを参考にした. 調査対象患者に おける腎機能評価には糸球体ろ過量（GFR）を反映する $\mathrm{CCr}$ を用い，その実測值としては S-CRE，尿中クレアチ ニン排出量, 測定開始後 1 時間目から 2 時間目までの尿
量，および体表面積より算出した術前腎機能モニタリン グ值を採用し，予測値としては Cockcroft-Gault 式にて 求めた值を採用した ${ }^{4)}$. 各薬剤における患者の $\mathrm{CCr}$ に対 応した投与設計は, 乾, 土井が編集した腎機能別薬剤使 用マニュアルに従った5).

\section{結果}

\section{1. 調査対象患者および薬㓮}

2000 年 6 月の 1 力月間における薬効分類別延べ処方日 数の集計結果を Table 1 に示した。消化器外科における 薬剂の使用動向調査ということもあり，輸液，ビタミン 鼡の延べ使用日数が最も多く, 次いで $\mathrm{H}_{2}$ 遮断薬, 下 剤，抗菌薬・抗ウイルス薬の順であった。これらの薬効 分類において腎排泄型薬剂が最も多かったのは抗菌薬 · 抗ウイルス薬であったため, 各抗生物質, ニューキノロ ン薬，抗真菌薬および抗ウイルス薬（以下，これらすべ ての薬剤を同一分類として抗菌薬と記載）を調査対象薬 剤とした。

調査対象期間の 1 年間における患者数は481人であ り，年齢分布は65歳以上の高齢者が全体の50\%を占めて いた（Table 2). 男女比は6：4であった。調査対象 薬剂は計44剤で, 調査対象患者の $96.7 \%$ にあたる465人 に用いられていた．剤形別延べ処方患者数を集計する と, 当科では手術前後において内服不可能な患者が多 く，また抗菌薬は治療においてある程度の濃度を必要と するため, 速やかに血中濃度が上昇する注射薬が内服薬 に比べ約 3 倍弱の頻度で用いられていた（Fig. 1$)$.

調査対象薬剂の中で，使用患者数が多かった上位 10 剂 における使用状況を Fig. 2 に示した. 最も多く使用さ れていた薬剤はセファゾリンであり, 調査対象薬剤使用

Table 1. 消化器外科における 1 力月間の薬効別延べ 処方日数

\begin{tabular}{cc}
\hline 薬効分類 & 延べ処方日数 (日) \\
\hline 輸液製郕 & 1949 \\
ビタミン剂 & 1499 \\
$\mathrm{H}_{2}$ 遮断薬 & 587 \\
下剂·止演薬 & 524 \\
*抗菌薬·抗ウイルス薬 & 495 \\
肝疾患治療薬 & 491 \\
晹疾患治療薬 & 470 \\
抗癌·免疫抑制薬 & 421 \\
健胃消化薬·胃腸機能調整薬 & 402 \\
非ステロイド抗炎症薬 & 396 \\
その他 & 3633 \\
\hline
\end{tabular}


Table 2. 調査内容

\begin{tabular}{|c|c|}
\hline 調盁項目 & 調査結果 \\
\hline 調查対象期間 & $1999 / 8 / 1 \sim 2000 / 7 / 31$ \\
\hline $\begin{array}{c}\text { 調査対象患者数 } \\
\text { 調査対象患者年龄 }\end{array}$ & 481 人 \\
\hline 平均値 & 60堿 \\
\hline 最小値 & 3些 \\
\hline 最大値 & 88歲 \\
\hline 年龄分布 & \\
\hline 10代以下 & 1人 \\
\hline 10 代 & 10人 \\
\hline 20代 & 20人 \\
\hline 30 代 & 21人 \\
\hline 40代 & 46人 \\
\hline 50 代 & 92人 \\
\hline 60 代 & $150 人$ \\
\hline 70代 & 117人 \\
\hline 80代以上 & 24人 \\
\hline 男女比 & $267: 214$ \\
\hline 調查対象薬剤数 & 44刻 \\
\hline 調㚗対象萫成投与患者数 & 465人 \\
\hline
\end{tabular}

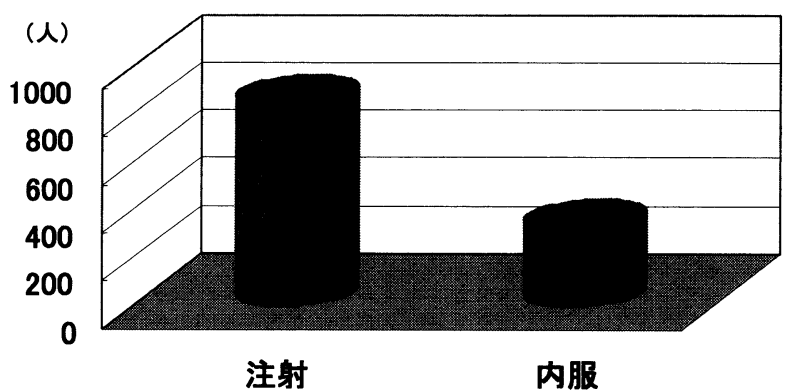

Fig. 1. 剂形別調查対象薬剤延べ処方患者数

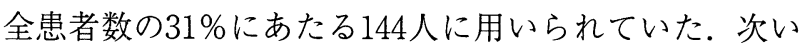
でフロモキセフ，レボフロキサシンの順であった。

\section{2. 薬剤の腎排泄率と使用頻度および患者の $\mathrm{CCr}$ の関 係}

実際に使用された抗菌薬の腎排泄率と使用頻度との関 係を Fig. 3 に示した。使用頻度は各抗菌薬が投与され た患者数を調查対象薬剤が投与された全患者数 465 人で 除した值とした。使用頻度の高かった上位 3 剂であるセ ファゾリン，フロモキセフ，レボフロキサシンはいずれ も腎排泄率が高く, 80\%以上が未変化体のまま腎臓から 排泄される薬剤であった。 また調査対象薬剤である抗菌 薬44剤のうち，65\%に相当する28剂は主排泄経路が腎で あった. Fig. 4 には使用頻度の高かった上位10剤の腎排 泄率とそれらの薬剤が実際に投与された患者の $\mathrm{CCr}$ 実 測值との関係を示した。 $\mathrm{CCr}$ が $60 \mathrm{~mL} / \mathrm{min}$ 以下の患者に 対し，腎排泄率が50\%を超える抗菌薬を使用する場合も
あり，通常投与量から減量しなければならない患者があ る程度存在していることが判明した。

\section{3. 患者の CCr に対応した投与設計}

使用頻度の高かったセファゾリン，フロモキセフ，レ ボフロキサシンにおいて，患者の CCr に対応した投与 設計を行う場合，各設定条件における患者数を集計した 結果をFig. 5 に示した. 抗菌スペクトルはやや狭いも のの, 治療域血中濃度上限が比較的高く, 腎機能低下患 者に対しても使用しやすい薬剤であるセファゾリンで は，投与設計が必要な患者は全体の $2 \%$ 程度であった。 フロモキセフでは約 $25 \%$ の患者になんらかの投与設計が 必要であり，常用量の $50 \%$ 以下に設定しなければならな い患者も10\%程度存在した。レボフロキサシンでも同様 の結果が得られ，通常 1 日 3 回の服用を 2 ないし 1 回に 減量しなければならない患者が $25 \%$ 程度存在した。

\section{4. $\mathrm{CCr}$ 実測值および予測值を用いた時の投与設定条件 における患者数の差異}

使用頻度の高い 3 剂において患者の腎機能に対応した 投与設計を行う際， $\mathrm{CCr}$ 実測值を用いた場合と予測值を 用いた場合の各投与設定条件における患者数の違いを Table 3 に示した. セファゾリンでは各々の患者数に違 いは見られなかったものの，フロモキセフあるいはレボ フロキサシンでは投与設計を行う際に CCr 予測値を用 いた場合，30\%前後の患者に不必要な減量を行ってしま うことになり, 治療上必要な血中濃度が得られない危険 性があることが確認された。また CCr 予測值が正常值 であっても実測值が低い患者もおり，減量せずに投与を 継続すると予期せぬ副作用症状が発現する可能性がある ことも確認された.

\section{考察}

本調査により当院消化器外科において最も使用頻度が 高かった薬剤は抗菌薬であることが判明した。当科にお ける患者は生体肝移植後の免疫抑制薬投与や各消化器癌 における抗癌薬投与により，免疫機能が著しく低下して いるだけでなく，術後の total parenteral nutrition（TPN） 管理やドレーン，カテーテルなどの挿入により極めて感 染しやすい状態にある，いわゆる compromised hostであ る。したがって, 抗菌薬が治療上重要な役割を担うこと は明らかである。抗菌薬が感染部位に最小発育濃度以上 移行するためにも，患者はある程度の血中濃度を得る必 要がある。一方, 抗菌薬は高血中濃度が持続すると副作 用発現の可能性が高くなるため, 体内動態を予測するこ とは重要である．抗菌薬のうち使用頻度が高かった上位 


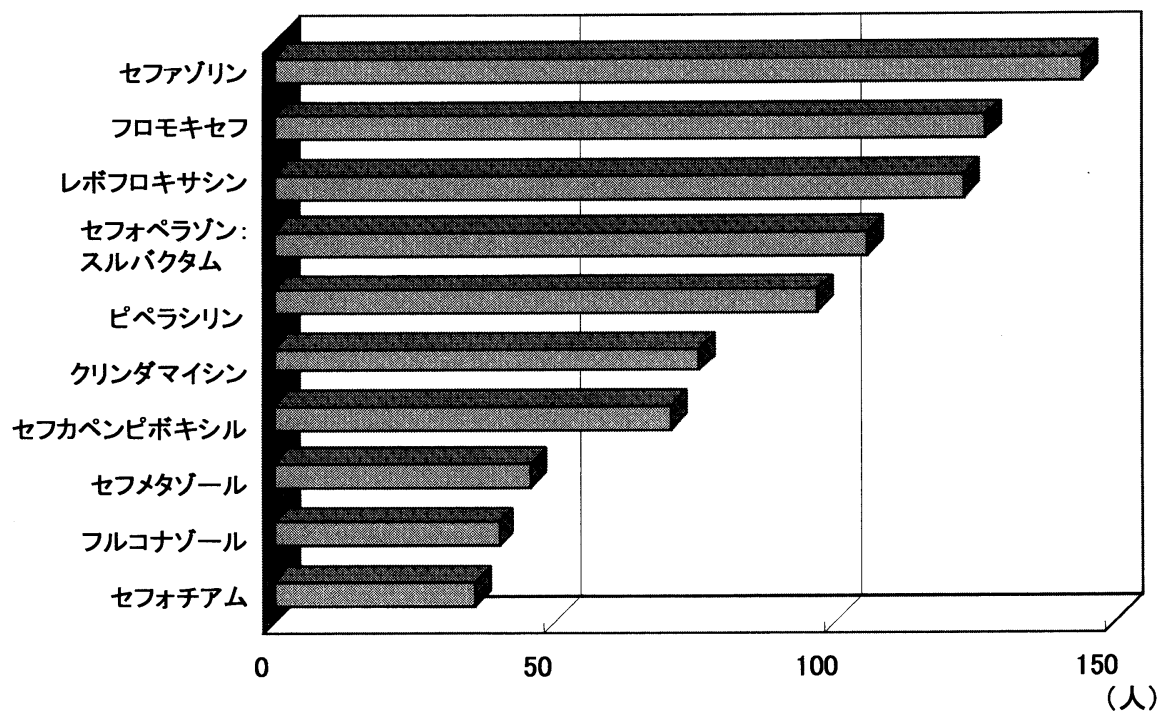

Fig. 2. 調査対象薬剤で使用頻度が高かった上位10剤における 延べ処方患者数

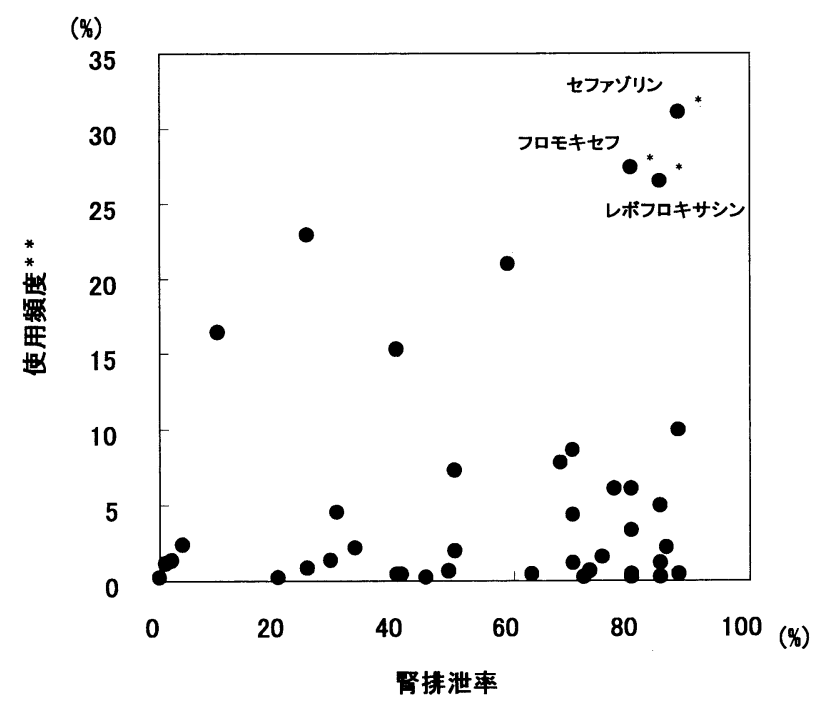

Fig. 3. 調査対象薬剤（全抗菌薬・抗ウイルス薬）の腎 排泄率と使用頻度の関係

*使用頻度が高かった上位 3 剂のみ Fig 中に一般 名を記載

$* *$ 使用頻度 $=$ 各調査対象薬剤使用患者数 $/$ 全調査 対象薬剂使用患者数（465人）

3 剂はいずれも腎排泄率が $80 \%$ を超えており，体内から の薬物の消失は $\mathrm{CCr}$ に相関している6-8).したがって, 患者の CCr に対応した抗菌薬の投与設計が必要であ る。当科に扔いて $\mathrm{CCr}$ が $60 \mathrm{~mL} / \mathrm{min}$ 以下の患者は全体の 10\%程度であり，これらの患者に腎排泄型抗菌薬が投与 される場合はなんらかの投与設計が必要となる。した がって，現在われわれはアミノグリコシド系のように postantibiotic effect を有する薬剂が腎機能低下患者に処 方された場合はその投与間隔を延長するよう，またセ フェム系のように有効濃度が維持されなければ効果が示 されない時間依存性の薬剂が妈方された場合はその投与 量を減量するよう ${ }^{9)}$ ，医師に情報をフィードバックして いる。

臨床上，簡便性の面から Cockcroft-Gault 式より求め た CCr 予測值を用いる場合がある。実際われわれが薬 物動態のモニターとしてこの予測值を使用する場合, 以 下の 2 点に関して注意を払っている。第 1 に, CCr 予測 值はある程度実測值を反映するが4)，高齢者においては 実測值と予測值が大きくかけ離れる可能性があることで ある3,4). 本調査結果においても CCr 低めに予測して しまう高齢患者が多かった。この理由として考えられる ことは，当科では手術に備えて循環動態などを輸液や利 尿薬で管理している患者が多いため，尿量が通常時より 安定していたためではないかと推測できる．また，フロ モキセフおよびレボフロキサシンの両薬剤において CCr に対応した投与設計を行う場合，予測值を用いると，約 30\%前後の患者に不必要な投与量の減量を行ってしまう 結果となった。したがって, 治療上必要な血中濃度が得 られない可能性があり，投与設計を行う際はこのことに 十分注意を払う必要があることが示唆された。また，数 名ではあるが予測值が実測值を大きく上回る患者もいた ため, Therapeutic Drug Monitoring (TDM) が必要な薬 剤においては CCr 予測值を投与設計に用いるべきでは ないことが示唆された。実際バンコマイシンの血中濃度 解析においても同様の結果が報告されている第 2 


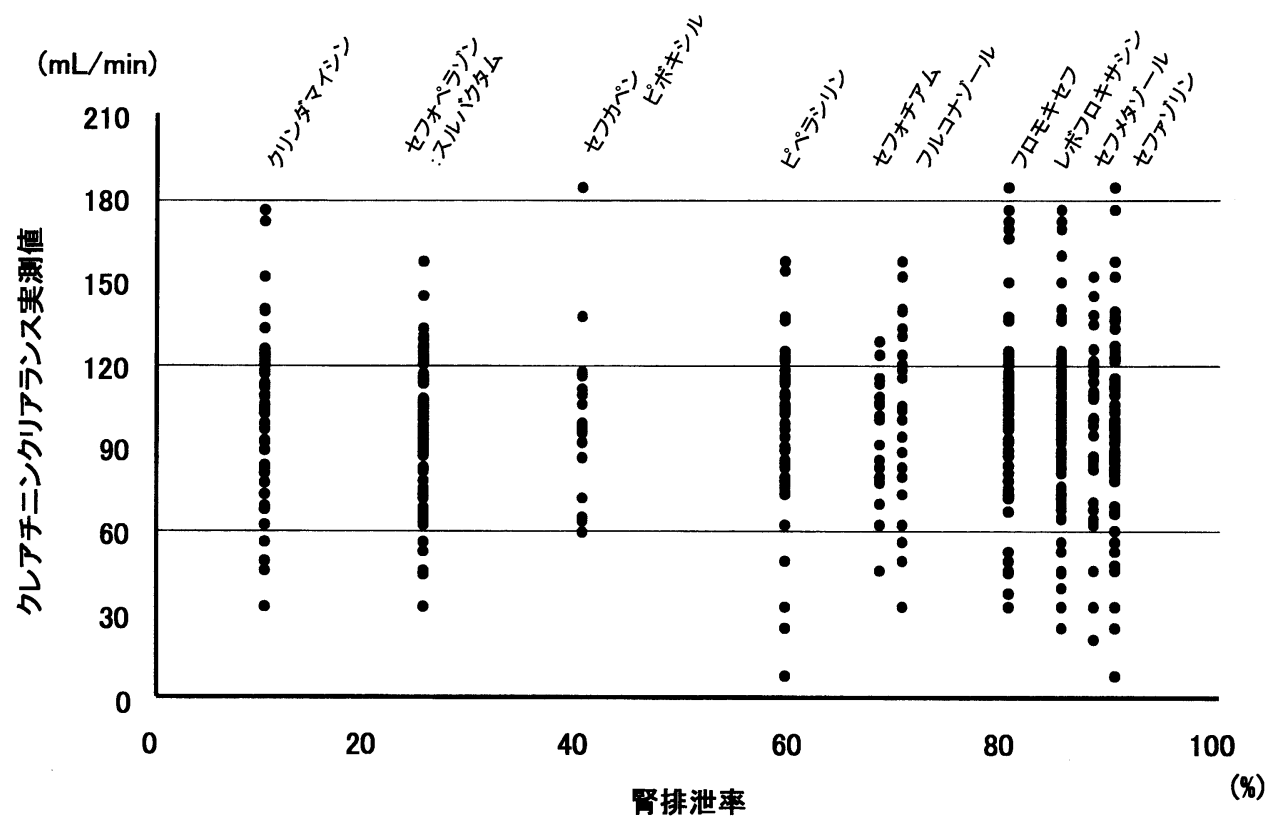

Fig.4. 使用頻度が高かった上位10剤の腎排泄率と実際に投与された 患者のクレアチニンクリアランス実測值との関係
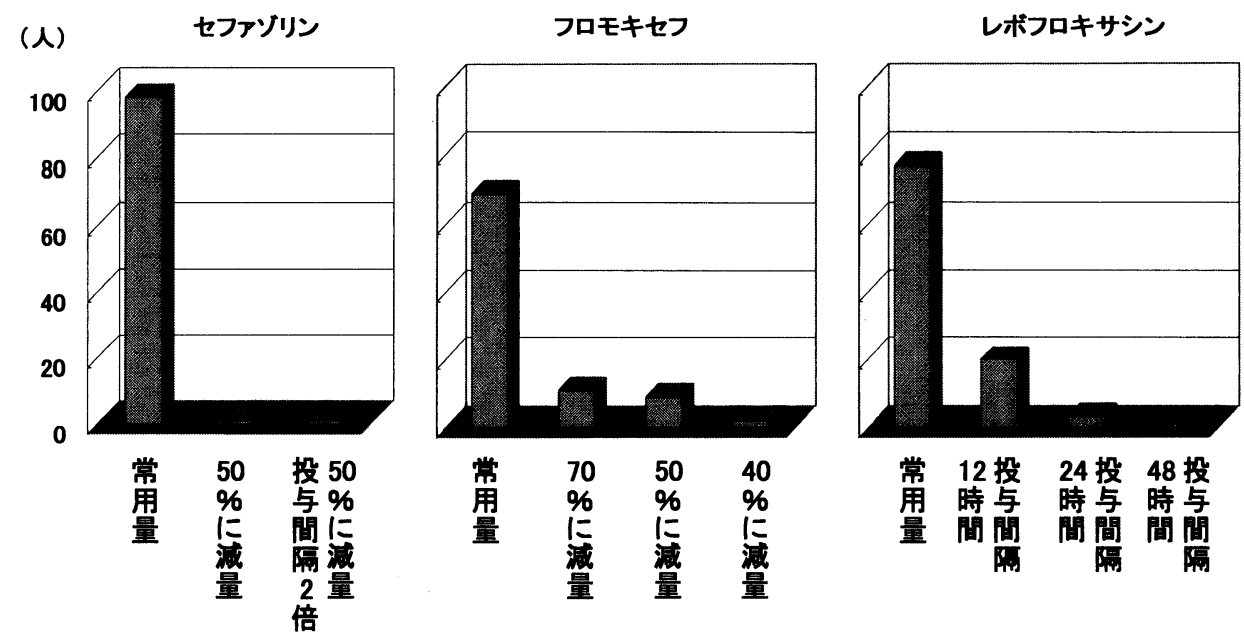

Fig. 5. クレアチニンクリアランスに対応した各投与設定条件における患者数

に，腎障害時には薬物の排泄だけでなくタンパク結合率 および分布容積も変動する可能性があることである。こ の点に関してもバンコマイシン投与患者において同様の 報告がなされている ${ }^{11,12)}$ 。したがって，投与設計前後の 白血球数や C-reactive protein (CRP), 尿量, 体温などの 情報も把握したうえ，現在の投与量で患者の症状が改善 していることを確認しながら最適投与量を決定していく 必要があることも示唆された。

本調査結果をふまえ, われわれが行っている業務の現 状を記載した，本業務を円滑に行うため，Microsoft Ac$\mathrm{cess}^{\circledR}$ を用いて薬歴を入力している. Fig. 6 にはシステ
ムの 1 部である注射薬歴入力画面を示した．画面上部の 検査值時系列にて患者の S-CRE 情報を把握し, 画面下 の CCr 変換ボタンにより Cockcroft-Gault 式にて CCrを 自動的に予測し，さらに CCr 実測值が測定されている 場合にはその值と比較しがら, 薬歴入力を行っている. この際, CCr 実測值が不明で, S-CREからの予測值が処 方薬剤の投与設定条件ギリギリにあり，その必要性を医 師に伝えるべきか否かを迷う場合においては，対象患者 にあらかじめ服薬指導を行い予期される副作用症状を伝 え，もし副作用初期症状を患者が訴えたならば，これら の情報を積極的に医師に伝え投与設計を行うべきか否か 
医療薬学 Vol. 27,No. 4 (2001)

Table 3. 投与設計の際に用いる CCr の違いによる各設定範囲における患者数の比較

\begin{tabular}{|c|c|c|c|c|c|c|}
\hline \multirow{2}{*}{ 薬用名 } & \multirow{2}{*}{ 設定範囲 } & \multirow{2}{*}{ 設定条件 } & \multicolumn{2}{|c|}{ CCr実測值探用 } & \multicolumn{2}{|c|}{ cCr予測值採用 } \\
\hline & & & 患者数 & $\%$ & 患者数 & $\%$ \\
\hline \multirow[t]{3}{*}{ セファソリン } & $\mathrm{CCr} \geqq \mathbf{3 0}$ & 常用量 & 98 & 98.0 & 98 & 98.0 \\
\hline & $10 \leqq c C r<30$ & 50\%1墄量 & 1 & 1.0 & 1 & 1.0 \\
\hline & $\mathrm{cCr}<10$ & $\begin{array}{c}\text { 50\%1に減量 } \\
\text { 投与間2倍 }\end{array}$ & 1 & 1.0 & 1 & 1.0 \\
\hline \multirow[t]{4}{*}{ フロモキセフ } & $\mathrm{CCr} \geqq 80$ & 常用量 & 69 & 75.8 & 47 & 51.6 \\
\hline & $60 \leqq \mathrm{CCr}<80$ & 70\%1二淢量 & 11 & 12.1 & 26 & 28.6 \\
\hline & $40 \leqq c C r<60$ & 50\%に減量 & 9 & 9.9 & 14 & 15.4 \\
\hline & $\mathrm{CCr}<40$ & 40\%に減量 & 2 & 2.2 & 4 & 4.4 \\
\hline \multirow[t]{4}{*}{ レボフロキサシン } & $\mathrm{CCr} \geqq 70$ & 常用量 & 77 & 76.2 & 46 & 45.5 \\
\hline & $40 \leqq c C r<70$ & 投与間隔 $12 \mathrm{~h}$ & 20 & 19.8 & 51 & 50.5 \\
\hline & $20 \leqq c C r<40$ & 投与間隔24h & 3 & 3.0 & 4 & 4.0 \\
\hline & $\mathrm{CCr}<20$ & 投与間隔48h & 1 & 1.0 & 0 & 0.0 \\
\hline
\end{tabular}

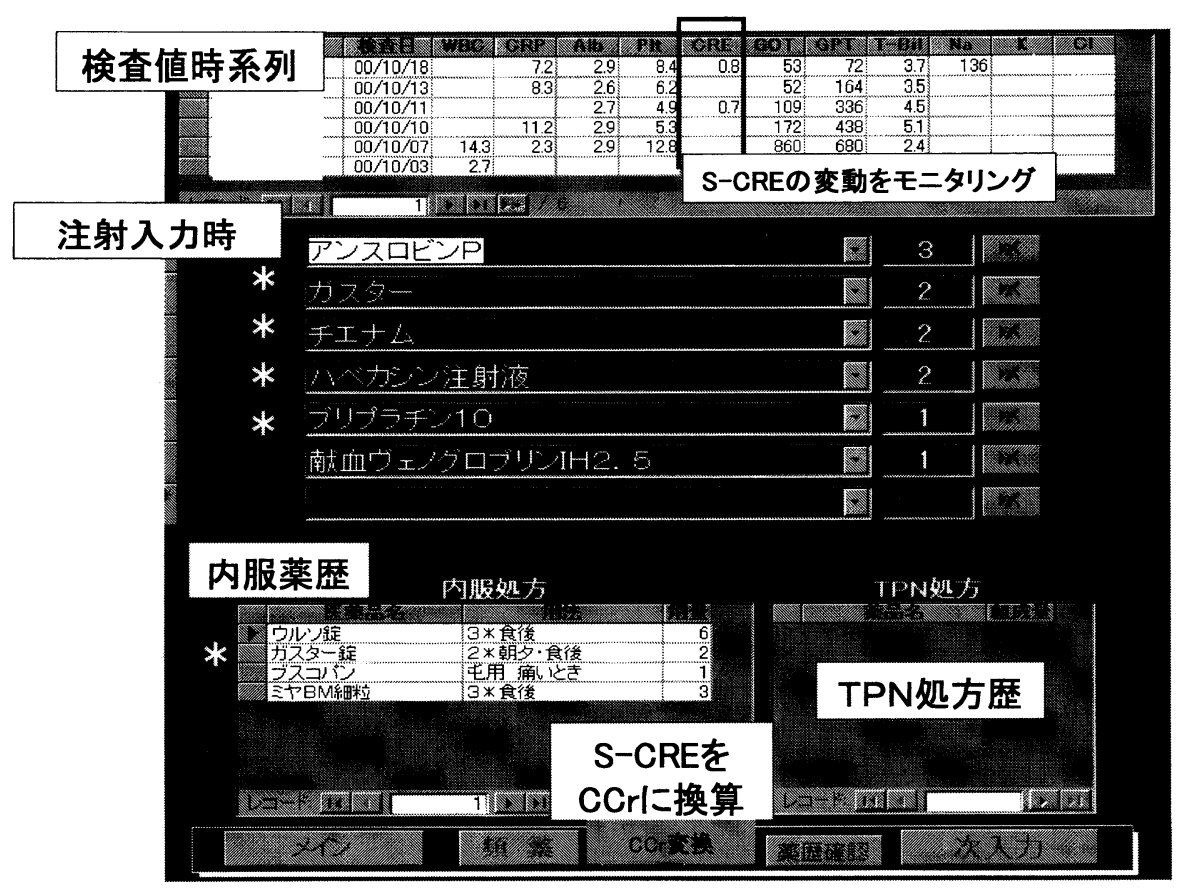

＊腎俫泄型薬舤

Fig. 6. Microsoft Access ${ }^{\circledR}$ を用いた注射薬歴入力画面

を決定している.TDM 対象薬剤以外は実際投与された 抗菌薬の血中濃度を測定しているわけではないので, Pharmacokineticsの予想から得られる情報からだけでは 投与設計を行うにあたり限界がある。したがって，服薬 指導を通して患者から得られるPharmacodynamicsな情 報も加味しながら行うようにしている．CCrを $10 \mathrm{~mL} /$ min 刻みで正確に予測することにより得られるデーター
からは臨床上有益な情報が得られないことがあるため， 最終的に必ず医師の判断のもとに投与設計を行うことが 重要であると思われる。実際われわれはこれらの業務を 行うことで，上昇傾向にあった S-CREが抗菌薬の減量 により正常值まで回復した症例や，減量した場合でも感 染症状に十分効果を示した症例を経験することができ た。 
本調査結果から, 消化器外科においては腎排泄型抗菌 薬が非常に高い頻度で用いられていること, また入院患 者の 10 人に 1 人はこれら薬剤に対しなんらかの投与設計 を必要とする CCrであることを再確認した。薬郕師は 薬歴管理, 服薬指導, TDM どのファーマシューティ カル・ケアを通じて, 医薬品の適正使用に必要な情報を 提供する業務展開を行わなければならない。したがっ て, 投与された薬剤の排泄経路を把握し患者の排泄臓器 の機能に応じた投与量を設計し，その情報を医師および 患者にフィードバックすることは，今後の業務に反映さ せる重要な事項の1つであると考えられる。

\section{引用文献}

1) 全田浩, 林昌洋, 小池香代, 小林道也, プレアボ イドの推進，日病薬誌，36，1055-1067(2000).

2）和泉智, 平田純正, 大年辰幸, 田中一彦, 透析と 薬物療法, 月刊薬事, 40, 3273-3285(1998).

3) R.W. Jelliffe, Creatinine clearance : bedside estimate, Ann. Intern. Med., 79, 604-605(1973).

4) D.W. Cockcroft, Prediction of creatinine clearance from serum creatinine, Nephron, 16, 31-41(1972).

5）乾賢一，土井俊夫, “腎機能別薬剤使用マニュア ル”，薬業時報社，東京，1999，pp. 108-141.

6) 木下康民, 山作房之助, 土田亮, 武田元, 薄田芳 丸, 貝沼知男, 関根理, Cefazolinの基礎的なら びに臨床的研究, Chemotherapy, 18, 604-611 (1970).
7）中村光男, 中畑久, 平井裕一, 熊坂義裕, 猪岡元, 武部和夫, 腎機能障害患者における Flomoxef (6315-S）の体内動態, 最新医学, 42, 1715-1721 (1987).

8) 斉藤昭弘, 小口健一, 原田吉将, 篠田育男, 米田 尚生, 岡野学, 伊藤康久, 藤広茂, 兼松稔, 坂義 人, 河田幸道, 蟹本雄右, 岡田謙一郎, 西古靖, 斎藤功，腎機能障害患者における Levofloxacinの 体内動態の検討, Chemotherapy, 40, 188-195 (1992).

9）齋藤玲, 各種抗菌薬の基本的な使い分け, 臨床と 薬物治療，15，286-288(1996).

10) M. Yasuhara, T. Iga, H. Zenda, K. Okumura, T. Oguma, Y. Yano, R. Hori, Population pharmacokinetics of vancomycin in japanese adult patients, Ther. Drug. Monit., 20, 139-148(1998).

11) E.Polard, Vincent, V.L. Bouquin, P.L. Corre, C.Kerebel, H.Trout, A.Feuillu, R.L. Verge, Y.Malledant, Non steady state and steady state PKS bayesian forecasting and vancomycin pharmacokinetics in ICU adult patients, Ther. Drug. Monit., 21, 395-403 (1999).

12) K. Morita, A. Yamaji, Changes in the serum protein binding of vancomycin in patients with methicillinresistant Staphylococcus aureus infection : the role of serum alpha 1-acid glycoprotein levels, Ther. Drug. Monit., 17, 107-112(1995). 